\title{
Blood Fluke Infection of Cultured Tiger Puffer Takifugu rubripes Imported from China to Japan
}

\author{
Kazuo Ogawa ${ }^{1 *}$, Taizo Nagano ${ }^{2}$, Noriko Akai ${ }^{2}$, Akihiro Sugita ${ }^{3}$ \\ and Kathryn A. Hall ${ }^{1}$ \\ ${ }^{1}$ Department of Aquatic Bioscience, Graduate School of Agricultural and Life Sciences, \\ The University of Tokyo, Bunkyo, Tokyo 113-8657, Japan \\ ${ }^{2}$ Kagawa Prefectural Fisheries Experimental Station, Takamatsu, \\ Kagawa 761-0111, Japan \\ ${ }^{3}$ Fukui Prefectural Fisheries Experimental Station, Tsuruga, \\ Fukui 910-0843, Japan
}

(Received January 15, 2007)

\begin{abstract}
Monthly samplings of tiger puffer Takifugu rubripes, which had been cultured in China and later introduced to a farm in Kagawa Prefecture, Japan, in May 2005, were conducted over a four-month period commencing in June 2005. Blood flukes were found in the visceral vascular system with the highest number being 162 worms/fish, and their eggs accumulated in the visceral organs. The parasite was classified within the genus Psettarium based on the unique male reproductive system, and tentatively designated as Psettarium sp. TPC (= tiger puffer from China). Molecular analyses, using the ITS2 rDNA gene indicated that the blood flukes of tiger puffer from two other sources (cultured in China and subsequently in the Kyushu area, and cultured in China only) were also Psettarium sp. TPC. This suggests that the infection cycle of Psettarium sp. TPC has been established in China. On the other hand, no evidence was found that its life cycle is complete in Japanese waters. Similar blood flukes were collected in 1993 from postspawned tiger puffer caught in a set-net in Wakasa Bay, Fukui Prefecture and maintained there for several months. This parasite was differentiated from Psettarium sp. TPC by the presence of 5-6 rows of pre-oral spines and designated as Psettarium sp. TPJ (= tiger puffer from Japan).
\end{abstract}

Key words: Psettarium, blood fluke, Takifugu rubripes, tiger puffer, mortality

The culture of tiger puffer Takifugu rubripes has a history of more than 50 years (Okamoto, 1963). In earlier times, post-spawned puffer (1-3 kg in body weight) caught by set-nets in spring and summer were cultured until winter, when puffer were marketed. This type of culture, though much smaller in scale than the present one, is still conducted in Wakasa Bay, Sea of Japan. In 1993, mortalities occurred among such large tiger puffer kept in captivity, and they were found heavily infected with an unidentified blood fluke of the genus Psettarium (Digenea, Sanguinicolidae) in the visceral vascular system ${ }^{\dagger}$.

\footnotetext{
* Corresponding author

E-mail: aogawak@mail.ecc.u-tokyo.ac.jp

† Tanaka, D., S. Wada, K. Hatai, A. Sugita and K. Ogawa. Histopathology of captive tiger puffer infected with a blood fluke. Abstract of oral presentation at the meeting of Japanese Society of Fish Pathology held at Tokyo Univ. of Fish. on March 31, 1995, p. 17.
}

Since the 1980s, the culturing of tiger puffer has dramatically increased. Currently, the culture of postspawned fish has been mostly replaced by the culture of artificially produced seeds of about $5 \mathrm{~cm}$ in body length (Takaoka, 2000). Recently, larger culture seeds, produced and cultured in China for up to one year, are imported to Japan. These seeds grow to marketable size in a considerably shorter culture period (about a half year) in Japan than the small juveniles produced domestically (about one year and a half). In 2005, some of the imported tiger puffer and large seeds to be shipped to Japan from China were found heavily infected with an unidentified blood fluke.

In the present case, 18,300 fish imported from China in May 2005 were introduced into net cages in the Seto Inland Sea off Kagawa Prefecture and started on a diet of minced fish. Mortality began to occur within three days of introduction and more than half of the stock 
was lost in three months. Since the fish we examined were heavily infected with a blood fluke, similar to the case of tiger puffer in Wakasa Bay in the summer of 1993, we suspected that blood fluke infection was the cause of the mortality.

Since blood fluke infection has never been recorded among net cage cultured tiger puffer in Japan, several questions were raised. The first question, with regard to the origin of the parasite, was whether the blood fluke was an introduced parasite from China or an indigenous one. Secondly, concerning its identity, it was unknown whether the parasite was the same species as the one we collected from tiger puffer maintained in Wakasa Bay. Thirdly, the risk remains to be assessed whether the life cycle of this parasite has been established at the farm and whether the infection spreads to other culture sites.

To answer the first and second questions, we examined tiger puffer not only from the monthly samples in Kagawa Prefecture, but also from other sources, including wild ones and ones cultured in China, for blood fluke infection. The blood flukes from Kagawa Prefecture and those from Wakasa Bay were compared morphologically. Further, flukes from three different sources were examined for sequences of the ITS2 region of rDNA gene to know their genetic identity. To answer the third question, we analised the results of the parasitological surveys on tiger puffer from different sources.

\section{Materials and Methods}

Monthly survey of blood fluke infected tiger puffer imported from China

One-year-old tiger puffer (19.8-28.6 cm in body length, 314-712 $\mathrm{g}$ in body weight; $\mathrm{n}=22$ ) were examined monthly from June 29, 2005 until October 18, 2005. These puffer had been reared and cultured in China until May 2005, and subsequently imported to Japan and cultured in western Kagawa Prefecture (Table 1-1). Sampled fish were transported to Kagawa Prefectural Fisheries Experimental Station for inspection. Visceral tissues and organs (liver, spleen, kidney, intestine, gonads, heart and gills) of tiger puffer were observed macroscopically and wet mount preparations were examined microscopically. In the first three months, the intestine, gonads or heart was not checked for parasite eggs. The eggs in the viscera were photographed on September 14, 2005 for the measurement of their size.

On June 29, 2005, the livers, kidneys and brains of four tiger puffer $(21.7-22.6 \mathrm{~cm}$ in body length, 381-430 $\mathrm{g}$ in body weight) were examined for possible bacterial infections, using $2 \% \mathrm{NaCl}$-added $\mathrm{BHI}$ agar (Nissui). The agar plates were incubated at $25^{\circ} \mathrm{C}$ for two days to allow bacterial growth.

The blood vessels of the viscera of tiger puffer were cut in several places with scissors and soaked in physi-

Table 1. Record of samplings (tiger puffer imported from China)

1) Kagawa Prefecture (monthly samples)

\begin{tabular}{lccccc}
\hline Date of survey & $\begin{array}{c}\text { No. of fish } \\
\text { examined }\end{array}$ & $\begin{array}{c}\text { Body } \\
\text { weight }(\mathrm{g})\end{array}$ & $\begin{array}{c}\text { Body } \\
\text { length }(\mathrm{cm})\end{array}$ & $\begin{array}{c}\text { No. of fish } \\
\text { with parasites }\end{array}$ & $\begin{array}{c}\text { No. of fish with } \\
\text { parasite eggs }\end{array}$ \\
\hline 2005. 6.29 & 4 & $381-430$ & $21.7-22.6$ & $1($ ND*) & 4 \\
2005. 7. 4 & 5 & $317-385$ & $19.8-22.3$ & $5\left(44-162^{* *}\right)$ & 5 \\
2005. 8.10 & 6 & $367-466$ & $21.6-24.1$ & $1\left(23^{* *}\right)$ & 5 \\
2005. 9.14 & 4 & $314-693$ & $19.8-27.4$ & $2\left(9-10^{* *}\right)$ & 4 \\
2005.10. 8 & 3 & $488-712$ & $25.9-28.6$ & 0 & 3 \\
\hline
\end{tabular}

* ND: number of flukes not determined

**: Number of flukes collected per fish

2) Farm $A$ in Kyushu

\begin{tabular}{lccccc}
\hline Date of survey & $\begin{array}{c}\text { No. of fish } \\
\text { examined }\end{array}$ & $\begin{array}{c}\text { Body } \\
\text { weight }(\mathrm{g})\end{array}$ & $\begin{array}{c}\text { Body } \\
\text { length }(\mathrm{cm})\end{array}$ & $\begin{array}{c}\text { No. of fish } \\
\text { with parasites }\end{array}$ & $\begin{array}{c}\text { No. of fish with } \\
\text { parasite eggs }\end{array}$ \\
\hline 2005. 6.15 & 5 & $297-493$ & $19.8-25.0$ & $5\left(4-112^{*}\right)$ & 5 \\
\hline *: Number of flukes collected per fish & & & & \\
3) Farm B in Kyushu & $\begin{array}{c}\text { No. of fish } \\
\text { examined }\end{array}$ & $\begin{array}{c}\text { Body } \\
\text { weight }(\mathrm{g})\end{array}$ & $\begin{array}{c}\text { Body } \\
\text { length }(\mathrm{cm})\end{array}$ & $\begin{array}{c}\text { No. of fish } \\
\text { with parasites }\end{array}$ & $\begin{array}{c}\text { No. of fish with } \\
\text { parasite eggs }\end{array}$ \\
\hline Date of survey & 3 & $263-336$ & $19.7-22.4$ & 0 & 2 \\
\hline 2006. 1.12 & & & & 0 & 2 \\
\hline
\end{tabular}


ological saline for up to $3 \mathrm{~h}$ to allow blood flukes to emerge from the vascular system. Collected blood flukes were flattened between a slide glass and coverslip, and fixed in AFA (70\% ethanol 20 parts, formalin 1 part, acetic acid 1 part). Flukes were stained with Heidenhain's iron hematoxylin, dehydrated, cleared in creosote or xylene, and mounted in Canada balsam for morphological observation under a light microscope. A total of 81 whole-mounted and stained specimens were prepared $(45,23$ and 13 specimens collected in July, August and September, 2006, respectively).

\section{Blood fluke infection of other groups of tiger puffer}

Besides the monthly samples, we had an opportunity to inspect blood fluke infections of tiger puffer from different sources: 1) tiger puffer imported from China and cultured in the Kyushu area (two farms different from that of the monthly samples, both of which were positive for blood fluke infection in a preliminary inspection) (Tables $1-2$ and $1-3)$; 2) tiger puffer cultured in China, frozen and sent to University of Tokyo for inspection (Table 2); 3) domestic tiger puffer cultured at the same farm as we made the monthly surveys in Kagawa Prefecture in 2005 and 2006 ( $n=10)$ (Table 3-1); 4) domestic tiger puffer cultured at different localities (Kagawa, Ehime, Nagasaki, Kumamoto and Fukui Prefectures) sampled in October-December 2006 (five fish from each lot in most cases; a total of 24 lots, $n=121$ ) (Table 3-2); 5) wild tiger puffer caught in trap nets in Wakasa Bay, Fukui Prefecture and maintained in captivity there for several months (Table 3-3); and 6) wild tiger puffer sent directly to market in Shimonoseki, Yamaguchi Prefecture (Table $3-4)$.

Tiger puffer from all of these categories were subjected to parasitological examination individually, as for the monthly samplings. When blood flukes were found, the intensity of infection was determined and the flukes, when alive, were processed to prepare stained specimens in the same way as in the monthly samplings. For domestic tiger puffer cultured in the five prefectures ( $n=121$; Table 3-2) and those from the farm, where the monthly samplings were conducted, collected in 2006 (n = 7; Table 3-1), only wet mount preparations of visceral tissues and organs were examined for parasite eggs.

Identification of the blood flukes

Stained whole-mounted specimens from the monthly sampled cultured tiger puffer in Kagawa Prefecture (fixed on August 10, 2005; $n=23$ ) and from tiger puffer captured and maintained in Wakasa Bay, Fukui Prefecture (fixed on August 3 and August 26, 1993; $n=$ 16) were examined morphologically. Voucher specimens of Psettarium japonicum collected from tiger puffer in the East China Sea (Yamaguti, 1938) [deposited in Meguro Parasitological Museum, M. P. M. Coll. No. SY61-28; one specimen] and from panther puffer, Takifugu pardalis, at Hamajima, Mie Prefecture, Japan (Yamaguti, 1951) [M. P. M. Coll. No. SY16-44; one complete specimen and the other with no posterior part] were also examined.

Blood flukes collected from defrosted tiger puffer cultured in China and later in the Kyushu area, and those from cultured tiger puffer sent from China to our laboratory were not suitable for staining. To know if they are the same species as those from monthly sampled tiger puffer in Kagawa Prefecture, some of them (from Farm A in Table 1-2 and from samples on April 11, 2005 in Table 2), together with the monthly samples on June 29, 2005, were analysed using DNA sequence data. The second internal transcribed spacer (ITS2) of the ribosomal gene array has been demonstrated to be a reliable indicator of species boundaries for the Digenea (see review by Nolan and Cribb, 2005). In this study, we have used the ITS2 rDNA gene to assess the conspecificity of the Psettarium specimens from the same host fish (Takifugu rubripes) from different geographical locations (China and Japan).

Specimens were killed and fixed in 95\% ethanol. DNA was extracted from individual worms using the DNeasy Tissue kit and protocol (QIAGEN). A list of specimens included in the study is provided in Table 4. DNA was eluted into a volume of $200 \mu \mathrm{L}$ of elution buffer (QIAGEN) and stored at $-20^{\circ} \mathrm{C}$.

Target fragments of DNA were amplified by PCR using the primers GA1 (forward) (Anderson and Barker, 1998) and ITS2.2 (reverse) (Cribb et al., 1998). PCRs were performed using puReTaq Ready-To-Go PCR Beads (Amersham Biosciences) according to the manufacturer's instructions. Cycling for touchdown PCR was as follows: initial denaturation at $94^{\circ} \mathrm{C}$ for 3 min, 5 cycles of $94^{\circ} \mathrm{C}$ for $30 \mathrm{sec}, 58^{\circ} \mathrm{C}$ for $30 \mathrm{sec}, 72^{\circ} \mathrm{C}$ for $1 \mathrm{~min}, 10$ cycles of $94^{\circ} \mathrm{C}$ for $30 \mathrm{sec}, 58-0.2^{\circ} \mathrm{C}$ per cycle for $30 \mathrm{sec}, 72^{\circ} \mathrm{C}$ for $1 \mathrm{~min}, 15$ cycles of $94^{\circ} \mathrm{C}$ for 30 sec, $56^{\circ} \mathrm{C}$ per cycle for $30 \mathrm{sec}, 72^{\circ} \mathrm{C}$ for $1 \mathrm{~min}$, and final

Table 2. Record of samplings (tiger puffer sent from China)

\begin{tabular}{lccccc}
\hline Date of survey & $\begin{array}{c}\text { No. of fish } \\
\text { examined }\end{array}$ & $\begin{array}{c}\text { Body } \\
\text { weight }(\mathrm{g})\end{array}$ & $\begin{array}{c}\text { Body } \\
\text { length }(\mathrm{cm})\end{array}$ & $\begin{array}{c}\text { No. of fish } \\
\text { with parasites }\end{array}$ & $\begin{array}{c}\text { No. of fish with } \\
\text { parasite eggs }\end{array}$ \\
\hline 2005. 4.11 & 2 & $196-252$ & $18.5-19.5$ & $2\left(5-20^{*}\right)$ & 2 \\
2005. 8. 3 & 2 & $390-599$ & $21.4-26.0$ & $2(169-660 *)$ & 2 \\
2005. 9.23 & 2 & $412-421$ & $22.2-22.3$ & 0 & 1 \\
2005. 9.23 & 2 & $228-244$ & $17.2-18.0$ & 0 & 2 \\
\hline
\end{tabular}

*: Number of flukes collected per fish 
Table 3. Record of samplings (domestically cultured/ wild tiger puffer)

1) Domestically cultured tiger puffer from same farm as the one in which monthly surveys were conducted in Kagawa Prefecture

\begin{tabular}{cccccc}
\hline Date of survey & $\begin{array}{c}\text { No. of fish } \\
\text { examined }\end{array}$ & $\begin{array}{c}\text { Body } \\
\text { weight }(\mathrm{g})\end{array}$ & $\begin{array}{c}\text { Body } \\
\text { length }(\mathrm{cm})\end{array}$ & $\begin{array}{c}\text { No. of fish } \\
\text { with parasites }\end{array}$ & $\begin{array}{c}\text { No. of fish with } \\
\text { parasite eggs }\end{array}$ \\
\hline 2005.10 .18 & 3 & $381-470$ & $23.4-24.8$ & 0 & 0 \\
2006.10 .12 & 7 & $143-228$ & $15.2-18.0$ & NC* & 0 \\
\hline
\end{tabular}

*: Not checked

2) Domestically cultured tiger puffer sampled October-December 2006

\begin{tabular}{lccccc}
\hline $\begin{array}{c}\text { Prefecture } \\
\text { (No. of lots) }\end{array}$ & $\begin{array}{c}\text { No. of fish } \\
\text { examined }\end{array}$ & $\begin{array}{c}\text { Body } \\
\text { weight }(\mathrm{g})\end{array}$ & $\begin{array}{c}\text { Body } \\
\text { length }(\mathrm{cm})\end{array}$ & $\begin{array}{c}\text { No. of fish } \\
\text { with parasites }\end{array}$ & $\begin{array}{c}\text { No. of fish with } \\
\text { parasite eggs }\end{array}$ \\
\hline Kagawa (4) & 20 & $147-476$ & $15.0-22.7$ & NC* & 0 \\
Ehime (5) & 25 & $74-355$ & $14.1-20.5$ & NC* & 0 \\
Nagasaki (7) & 36 & $85-1040$ & $15.9-29.5$ & NC* & 0 \\
Kumamoto (5) & 25 & $86-230$ & $14.3-19.5$ & NC* $^{*}$ & 0 \\
Fukui (3) & 15 & $179-335$ & $17.3-20.5$ & NC* $^{*}$ & 0 \\
\hline
\end{tabular}

*: Not checked

3) Maintained in Wakasa Bay, Fukui Prefecture

\begin{tabular}{lccccc}
\hline Date of survey & $\begin{array}{c}\text { No. of fish } \\
\text { examined }\end{array}$ & $\begin{array}{c}\text { Body } \\
\text { weight }(\mathrm{kg})\end{array}$ & $\begin{array}{c}\text { Body } \\
\text { length }(\mathrm{cm})\end{array}$ & $\begin{array}{c}\text { No. of fish } \\
\text { with parasites }\end{array}$ & $\begin{array}{c}\text { No. of fish with } \\
\text { parasite eggs }\end{array}$ \\
\hline 1993. 8. 3 \& 8.26 & 7 & $0.80-1.76$ & $30-45$ & 7 (ND*) & 7 \\
2005. 7.12 & 4 & $0.75-1.85$ & $32.0-46.5$ & 0 & 0 \\
\hline
\end{tabular}

* ND: number of flukes not determined

4) Wild tiger puffer

\begin{tabular}{ccccc}
\hline Date of survey & $\begin{array}{c}\text { No. of fish } \\
\text { examined }\end{array}$ & $\begin{array}{c}\text { No. of fish } \\
\text { with parasites }\end{array}$ & $\begin{array}{c}\text { No. of fish with } \\
\text { parasite eggs }\end{array}$ & Locality \\
\hline 2005.11 .16 & 6 & 0 & 0 & Yamaguchi Pref. \\
2005.11 .21 & 1 & 0 & 0 & Nagasaki Pref. \\
2005.11 .21 & 3 & 0 & 0 & Unknown \\
2005.11 .21 & 7 & 0 & 0 & Republic of Korea \\
\hline
\end{tabular}

extension at $72^{\circ} \mathrm{C}$ for $10 \mathrm{~min}$.

The ABI BigDye ver 3.1 cycle sequencing kit (Applied Biosystems) was used to sequence amplified DNA fragments. Electrophoretograms were examined in TraceViewer (CodonCode Corporation, 1999; TraceViewer for Classic Mac OS. CodonCode Corporation, Massachusetts, USA, available from http:// www.codoncode.com/TraceViewer/download/index.htm) to confirm base-calls, and forward and reverse sequences were concatenated using Se-Al ver 2.0a9 (Rambaut, 2001). Sequences were manually aligned in Se-Al. Sequence analysis was conducted using PAUP* ver 4.b8 (Swofford, 1998). Pairwise comparisons of sequences were completed using the absolute number of differences and uncorrected " $p$ " values.

\section{Results}

Monthly survey of blood fluke-infected tiger puffer imported from China

We observed swelling of the visceral blood vessels, small white spots on the spleen and occasional hemorrhagic ascites in the body cavity. A few specimens of the monogenean Heterobothrium okamotoi were found on the branchial cavity wall of all the fish examined. No bacteria were isolated on $\mathrm{BHI}$ agar from the liver, kidney or brain.

Examinations of wet mount preparations of the viscera revealed that, in all except one fish (21/22), the liver, spleen, kidney, intestine, gonads, heart and gills contained many eggs, with occasional negative results in the intestine, gonads, heart or gills (Table 1-1). Eggs in the viscera were not quantified, but they sometimes occupied a substantial area of the tissue examined. White spots on the spleen noticed in gross observations were masses of parasite eggs (Fig. 1). No large differ- 


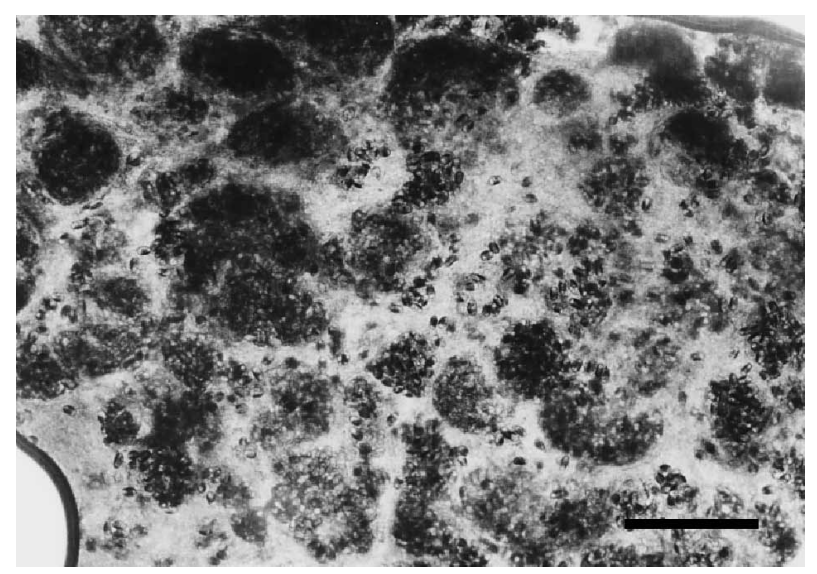

Fig. 1. Heavy accumulation of blood fluke eggs in a wet mount preparation of the spleen of cultured tiger puffer sampled on September 14, 2005. Scale bar: $0.5 \mathrm{~mm}$.

ences in egg size were noticed among eggs from the intestine $(n=50)$, kidney $(n=50)$, spleen $(n=30)$, testis ( $n=50)$ and gills $(n=11)$; these measurements were combined $(\mathrm{n}=191)$ : 34-69 $\mu \mathrm{m}$ long (mean $53.0 \mu \mathrm{m} \pm$ $6.24 \mu \mathrm{m} \mathrm{SD}$ ) by 26-39 $\mu \mathrm{m}$ wide (mean $32.1 \mu \mathrm{m} \pm 3.17$

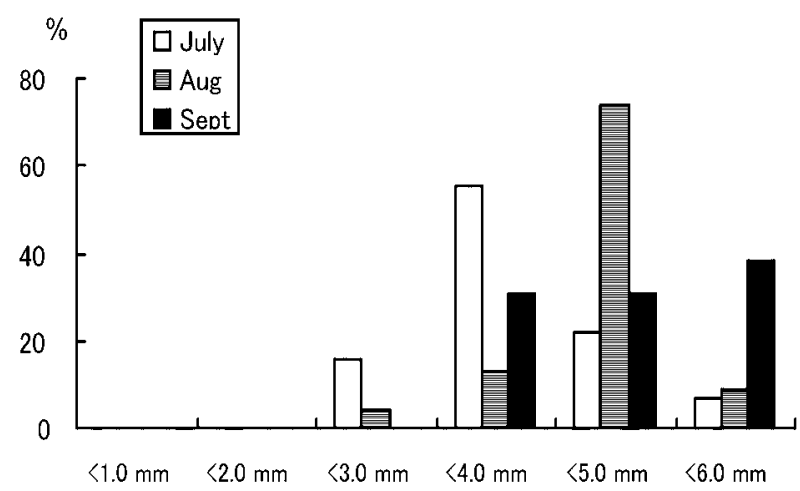

Fig. 2. Frequency distribution of body length of blood flukes collected from the monthly samples of cultured tiger puffer introduced from China to Kagawa Prefecture in 2005.

$\mu \mathrm{m}$ SD). Generally, eggs were quite variable in size and shape (elliptical to almost spherical), but this may be due to the angle at which eggs lay in the squash preparations.

On June 29, 2005 when the detection method of blood flukes had not yet been established, only one of

Table 4. A list of specimens included in the DNA study, including collection information and GenBank accession details

\begin{tabular}{|c|c|c|c|c|c|c|}
\hline $\begin{array}{l}\text { Sequence } \\
\text { Number }\end{array}$ & Host & Location & Country & $\begin{array}{l}\text { Collection } \\
\text { Date }\end{array}$ & $\begin{array}{l}\text { Specimen } \\
\text { Number }\end{array}$ & $\begin{array}{r}\text { GenBank } \\
\text { Accession }\end{array}$ \\
\hline 1 & T. rubripes & Kagawa & Japan & 05.07 .2005 & 1 & EF544037 \\
\hline 2 & T. rubripes & Kagawa & Japan & 05.07.2005 & 2 & EF544038 \\
\hline 3 & T. rubripes & Kagawa & Japan & 05.07.2005 & 3 & EF544039 \\
\hline 4 & T. rubripes & Kagawa & Japan & 05.07 .2005 & 4 & EF544040 \\
\hline 5 & T. rubripes & Kagawa & Japan & 05.07.2005 & 5 & EF544041 \\
\hline 6 & T. rubripes & Kyushu & Japan & 15.06.2005 & 1 & EF544042 \\
\hline 7 & T. rubripes & Kyushu & Japan & 15.06.2005 & 2 & EF544043 \\
\hline 8 & T. rubripes & Kyushu & Japan & 15.06 .2005 & 3 & EF544044 \\
\hline 9 & T. rubripes & Kyushu & Japan & 15.06 .2005 & 4 & EF544045 \\
\hline 10 & T. rubripes & & China & 04.11 .2005 & 1 & EF544046 \\
\hline 11 & T. rubripes & & China & 04.11 .2005 & 2 & EF544047 \\
\hline 12 & T. rubripes & & China & 04.11 .2005 & 3 & EF544048 \\
\hline 13 & T. rubripes & & China & 04.11 .2005 & 4 & EF544049 \\
\hline 14 & T. rubripes & & China & 04.11 .2005 & 5 & EF544050 \\
\hline
\end{tabular}

Table 5. Comparison of measurements of blood flukes of tiger puffer collected from different localities

\begin{tabular}{lcc}
\hline Locality & western Kagawa Prefecture & Wakasa Bay, Fukui Prefecture \\
Date of collection & 2005.8 .10 & $1993.8 .8 .3 \& 8.26$ \\
No. of specimens measured & 23 & 16 \\
\hline Body: Length & $2.9-5.0 \mathrm{~mm}$ & $6.3-9.8 \mathrm{~mm}$ \\
Oesophagus: Length & $0.58-1.26 \mathrm{~mm}$ & $1.05-1.49 \mathrm{~mm}$ \\
Anterior caecum: Length & $0.13-0.30 \mathrm{~mm}$ & $0.17-0.80 \mathrm{~mm}$ \\
Posterior caecum: Length & $0.8-2.2 \mathrm{~mm}$ & $1.4-4.5 \mathrm{~mm}$ \\
Posterior body part: Length* & $0.59-0.93 \mathrm{~mm}$ & $1.02-1.59 \mathrm{~mm}$ \\
Body spines & & \\
$\quad$ No. of rows & $380-550^{* *}$ & $610-830^{* * * *}$ \\
\multicolumn{1}{c}{ No. of spines/ row } & $<16^{* *}$ & $16-26^{* * *}$ \\
\hline
\end{tabular}

\footnotetext{
* Distance between anterior end of ovary and body end

** No. of specimens measured: 20

*** No. of specimens measured: 13
} 
the three fish was positive for the parasite in the vascular system, though numerous eggs were observed in viscera. On July 4, blood flukes were found in all the fish examined $(n=5)$, with the intensity of infection ranging from 44 to 162 (mean 83.0). In August to October, only three out of 13 fish were found infected, with the highest intensity being 10 (Table 1-1).

Of the 81 whole-mounted and stained specimens, all were matured, with the body length ranging from 2.4 $\mathrm{mm}$ to $5.7 \mathrm{~mm}$. When arranged at intervals of $1 \mathrm{~mm}$, the body length had the mode in the 3-4 mm, 4-5 mm and 5-6 $\mathrm{mm}$ class in July, August and September, respectively (Fig. 2). This shows a steady growth of the parasite during this period and no new recruitment of the parasite to the host.

\section{Blood fluke infection of other groups of tiger puffer}

In tiger puffer produced in Japan and cultured next to those imported from China $(n=3)$, no eggs were detected in the heart ventricle, liver, spleen, gonads, kidney or gills, and no blood flukes were collected from the visceral vascular system in a single fish (Table 3-1). Inspection conducted next year for the blood fluke infection of 0 -year-old tiger puffer in the same place $(n=7)$ was also negative (Table 3-1).

In tiger puffer imported from China and introduced to Kyushu, Japan, seven out of eight fish were positive for eggs, while flukes were recovered only from Farm A (Tables 1-2 and 1-3). The eight tiger puffer (4 lots) cultured in China, frozen and sent to our laboratory were all positive for blood fluke eggs (Table 2). Among them, flukes were found in four fish from two lots; the intensity was 5 and 20 in one group, whereas 169 and 660 flukes were collected from the other group. In contrast, no infection was confirmed for tiger puffer cultured in the five prefectures (Table 3-2).

Large tiger puffer caught with trap nets in Wakasa Bay, maintained for several months and sampled in August, 1993 were heavily infected with blood flukes (intensity of infection not determined), while in the surveys conducted in the same place 12 years later in 2005 , no infection was confirmed (Table 3-2). The wild tiger puffer from four localities were not infected (Table 33).

\section{Identification of the parasites}

Based on the descriptions of Psettarium japonicum by Goto and Ozaki (1929) (as Plehnia japonica Goto et Ozaki, 1929) and by Yamaguti (1951), the generic diagnosis of Psettarium given by Yamaguti (1958), and the examination of voucher specimens of $P$. japonicum collected by S. Yamaguti (Yamaguti, 1938; 1951), we classified the present blood flukes into the genus Psettarium. Morphological characteristics distinguishing these flukes from those of the other genera in the family Sanguinicolidae were the diffuse and widely dis-
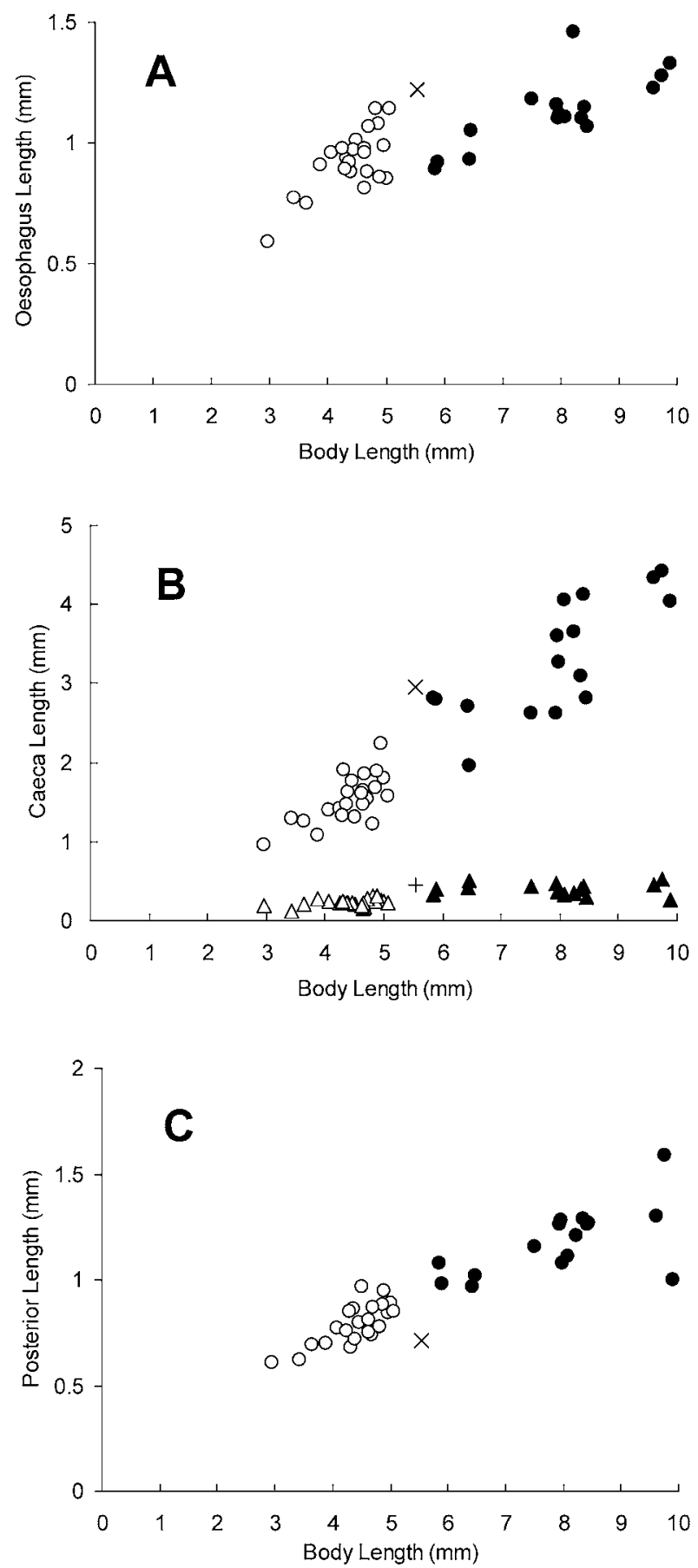

Fig. 3. Correlation of body length to oesophagus length (A), anterior and posterior caecum length $(B)$ and posterior part length $(\mathrm{C})$ of blood flukes collected from three different groups of tiger puffer. Open and closed symbols represent specimens from the monthly sampled tiger puffer in Kagawa Prefecture $(n=23$; fixed on August 10, 2005) and those from post-spawned tiger puffer in Wakasa Bay, Fukui Prefecture ( $n=16$; fixed on August 3 and August 26, 1993), respectively. Symbols $x$ and + represent the voucher specimen of Pettarium japonicum sensu Yamaguti (1938). For Fig. 3B, triangle and circle symbols are used for anterior and posterior caecum, respectively. 
tributed testis and the presence of a posterior vas deferens.

Measurements of the blood flukes are given in Table 5. Specimens from Wakasa Bay were larger than those from Kagawa Prefecture, and the measurements of the body length from the two localities did not overlap with each other, nor did the number of rows of body spines or the number of body spines in a row. Correlations of the body length with the oesophagus length, anterior and posterior caecum length or the posterior part length of the body (defined here as the distance from anterior end of the ovary to the end of the body) were examined between the two groups of blood flukes (Fig. 3). The measurements were largely different from each other, but fit in a similar linear relationship. There was, however, one clear difference between the two groups. In the Kagawa group, 5-6 rows of preoral rows of tiny spines were clearly visible, whereas, in the Wakasa group, such spines were not observed (Fig. 4). The voucher specimens of $P$.
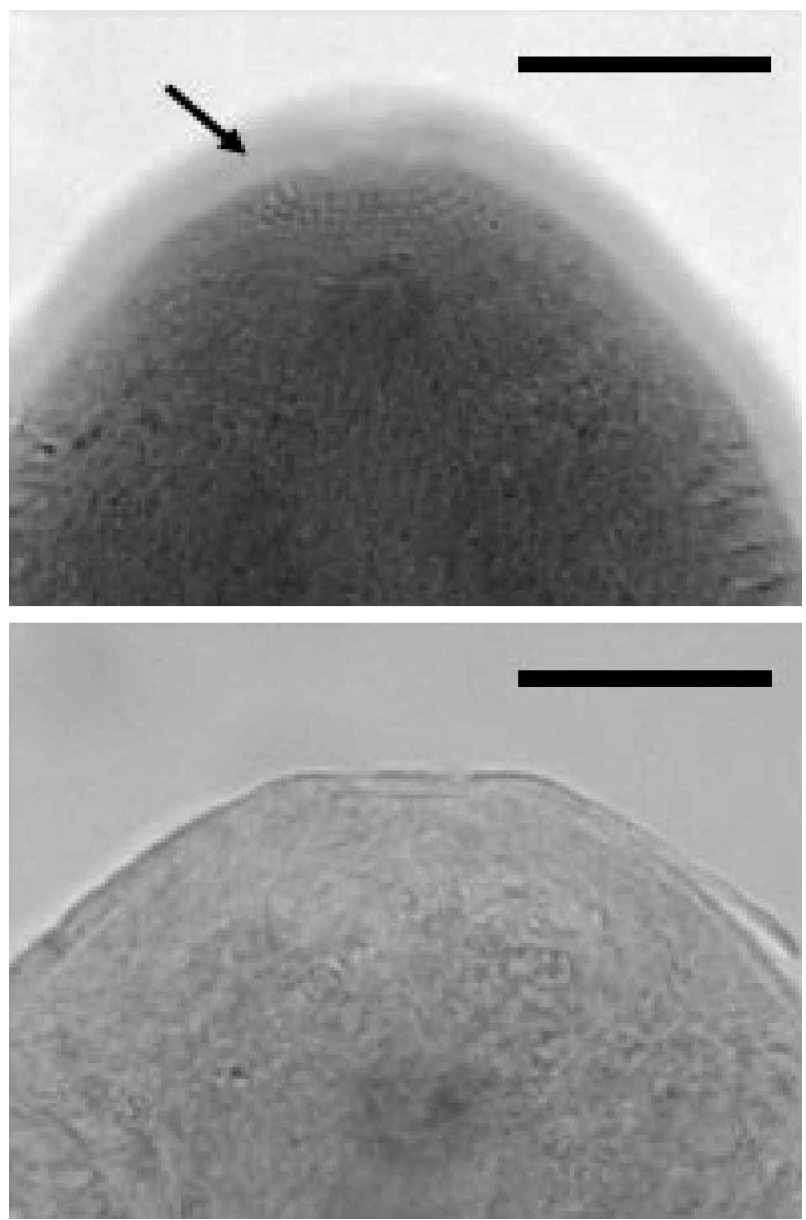

Fig. 4. Anterior part of blood flukes from tiger puffer in Kagawa Prefecture (top) and from post-spawned tiger puffer in Wakasa Bay, Fukui Prefecture (bottom). Arrow indicates rows of tiny spines. Heidenhain's iron hematocylin stain. Scale bar: $20 \mu \mathrm{m}$. japonicum collected from tiger puffer in the East China Sea (M. P. M. Coll. No. SY61-28) and from panther puffer in Mie Prefecture, Japan (M. P. M. Coll. No. SY1644) were slightly larger in body length $(5.54 \mathrm{~mm}$ and 5.38 $\mathrm{mm}$, respectively) than the specimens from Kagawa Prefecture, and measurements of the other body parts were not very different from each other (data not shown). Unfortunately, the deposited specimens are in poor condition, and we are unable to make a definitive assessment of the conspecifity of these specimens with our newly collected material.

Molecular data show that blood flukes collected from tiger puffer cultured in China and later in the Kyushu area, and those from cultured tiger puffer sent from China to our laboratory were the same species as those from the monthly sampled tiger puffer in Kagawa Prefecture. The alignment of the ITS2 rDNA sequences was 526 bases in length. The sequences showed a strong AT bias (3.707, $p=1.000)$. Each of the groups of specimens (host and location) was internally consistent, with the specimens from each collecting event being identical to the others from that collecting event. The specimens from T. rubripes from Japan (Kagawa and Kyushu) showed no base differences to the specimens from $T$. rubripes from China. The sequence data have been deposited in GenBank (Table 4).

\section{Discussion}

The blood fluke and the monogenean, Heterobothrium okamotoi, were the only pathogens detected in the tiger puffer during the period of monthly surveys. Intensity of infection of the monogenean parasite was too low to cause mortality and no noticeable mortality occurred among domestic tiger puffer cultured next to those introduced from China. Eggs of the blood fluke occupied large areas of the viscera and histological evidence suggests severe pathology associated with blood fluke infections (K. Ogawa, unpublished data). Thus, the cause of the mortality was thought to be the blood fluke infection.

Blood flukes in the present study were not identified to the species level because the genus Psettarium should be re-emended before their identification is determined. The type species of the genus Psettarium is $P$. japonicum, which was collected from panther puffer Takifugu pardalis in Japan. Unfortunately the type specimens of $P$. japonicum have been lost. Recently, Smith (2001) and Bullard and Overstreet (2006) both emended the genus independently, but their emendations were based on the morphology of other species, such as $P$. psettodorum from rockfishes, Sebastes spp., and $P$. tropicum from bullseye puffer, Spheroides annulatus, rather than that of the type species. The present two species have morphological characteristics 
in common with the type species, including a reticular testis covering the entire body from the level of oesophagus to almost the posterior end of the body and the presence of a posterior vas deferens (Goto and Ozaki, 1929). These characteristics are not known in other blood flukes, but were not included in recent emendations of Psettarium (Smith, 2001; Bullard and Overstreet, 2006). Emendation of Psettarium is beyond the scope of this paper and the present two species will be described and identified elsewhere, together with a rediagnosis of Psettarium.

Assuming that the blood flukes from tiger puffer (one-year-old) in Kagawa Prefecture and those from Wakasa Bay, Fukui Prefecture live long enough, measurements of the blood flukes from Kagawa Prefecture could be comparable to those of tiger puffer (probably three-years-old or older) from Fukui Prefecture. Further, it may be possible that the number of spine rows and the number of spines in one row increase as the parasite ages. However, the blood flukes from tiger puffer in Kagawa Prefecture had 5-6 rows of pre-oral rows of tiny spines, which were not observed in those from Fukui Prefecture. Together with the presence or absence of the pre-oral rows of spines and differences in measurements of body parts, it is concluded here that the blood flukes from the two groups were different from each other, each constituting an independent species. We tentatively designated those from tiger puffer cultured in China and later in Kagawa Prefecture as Psettarium sp. TPC and those from tiger puffer captured and maintained in Wakasa Bay, Fukui Prefecture, Japan as Psettarium sp. TPJ.

In the monthly surveys, tiger puffer were most heavily infected in July, 2005 and the prevalence and intensity of infection decreased considerably in the following months. It may be possible that the life span of the parasite in the final host was not long enough for the flukes to grow as large as the ones in the tiger puffer collected in Wakasa Bay in 1993.

Preliminary surveys of wild Japanese puffer of the genus Takifugu revealed that some of them were infected with blood flukes of the genus Psettarium (K. Ogawa, unpublished data). Liu (1997) described a new species Paradeontacylix sinensis collected from Takifugu oblongus in Fujian Province, China. Rather, it is similar in general morphology to $P$. japonicum and Psettarium sp. TPC, and may be best included in the genus Psettarium despite the lobed testis described by Liu. Further examination will be needed to clarify its taxonomic position.

The complete identity of the DNA data among blood flukes from monthly sampled tiger puffer in Kagawa Prefecture, those from tiger puffer cultured in China and later in the Kyushu area, and those from tiger puffer sent from China to our laboratory suggests that these specimens are best interpreted as belonging to the one species. This interpretation of the data is consistent with the review of ITS2 rDNA sequence data for the Digenea presented by Nolan and Cribb (2005). Nolan and Cribb (2006a, b) have used the standard of complete identity to interpret species boundaries for other genera of sanguinicolids in the Indo-west Pacific. Nolan and Cribb (2005; 2006a, b) believe that small base differences (1-2 bases across the entire ITS2 rDNA region), when consistent with observable morphological variation, can be used to assert species boundaries. We concur with this view. In the absence of genetic variation, and the morphological similarities of the sets of specimens, we interpret them as all belonging to the species Psettarium sp. TPC.

The result that cultured tiger puffer sent from China to our laboratory were infected with Psettarium sp. TPC indicates that the blood fluke infection occurs among culture tiger puffer in China. In contrast, no infection was confirmed in tiger puffer originating from domestically produced culture seeds, and no new infection had been acquired among the monthly sampled tiger puffer since they were introduced into Japan. These observations suggest that the infection cycle of Psettarium sp. TPC is not yet established in Japanese waters. Similar blood fluke infections occurred among tiger puffer caught and maintained in Wakasa Bay in 1993. The present study demonstrates that Psettarium sp. TPC, the blood fluke introduced from China, is a different species from Psettarium sp. TPJ found in Wakasa Bay in Japan. The life-cycle of blood flukes of the genus Psettarium is unknown. Although there is no evidence that the lifecycle of Psettarium sp. TPC has not yet been completed in Japanese waters, there still remains a risk of the completion of its life-cycle among Japanese species of Takifugu, including tiger puffer, and is recommended that further introduction of infected tiger puffer from China should be avoided.

\section{Acknowledgements}

We would like to thank the following people; Dr. A.$X$. Li, The School of Life Science, Zhongshan University, China, for sending us the paper by Liu (1997); people from Ehime, Kumamoto, Nagasaki and Fukui Prefectures for sending us tiger puffer samples; Mr. $\mathrm{H}$. Matsumura, Managing Director, Shimonoseki Karato Fish Market Co., Ltd., for providing us with viscera of wild tiger puffer; Dr. J. Araki, Meguro Parasitological Museum, Tokyo, for lending us deposited specimens of Psettarium japonicum collected by Dr. S. Yamaguti. We also thank Dr. S. Shirakashi and students of KO's Lab and Ms. K. Yoshizawa, Department of Veterinary Medicine, Nihon University, Fujisawa, Kanagawa Prefecture, for their help in the parasitological examination of tiger puffer sampled in Japan and China. This study was partly supported by the grant from the Japan Fisher- 
ies Resource Conservation Association given to $\mathrm{KO}$.

\section{References}

Anderson, G. R. and S. C. Barker (1998): Inference of phylogeny and taxonomy within the Didymozoidae (Digenea) from the second internal transcribed spacer (ITS2) of ribosomal DNA. Syst. Parasitol., 41, 87-94.

Bullard, S. A. and R. M. Overstreet (2006): Psettarium anthicum sp. n. (Digenea: Sanguinicolidae) from the heart of cobia Rachycentron canadum (Rachycentridae) in the northern Gulf of Mexico. Folia Parasitol., 53, 117-124.

Cribb, T. H., G. R. Anderson, R. D. Adlard and R. A. Bray (1998): A DNA-based demonstration of a three-host lifecycle for the Bivesiculidae (Platyhelminthes: Digenea). Int. J. Parasitol., 28, 1791-1795.

Goto, S. and Y. Ozaki (1929): Brief notes on new trematodes, II. Japan. J. Zool., 2, 361-381.

Liu, S.-F. (1997): Two new species of trematodes of marine fishes from Fujian, China (Trematodea; Digenea). Acta Zool. Sinica, 22, 118-124. (in Chinese)

Nolan, M. J. and T. H. Cribb (2005): The use and implications of ribosomal DNA sequencing for the discrimination of digenean species. Adv. Parasitol., 60, 101-163.

Nolan, M. J. and T. H. Cribb (2006a): An exceptionally rich complex of Sanguinicolidae von Graff, 1907 (Platyhelminthes: Trematoda) from Siganidae, Labridae and Mullidae (Teleostei: Perciformes) from the Indo-west Pacific region.
Zootaxa, 1218, 1-80.

Nolan, M. J. and T. H. Cribb (2006b): Cardicola Short, 1953 and Braya n. gen. (Digenea: Sanguinicolidae) from five families of tropical Indo-Pacific fishes. Zootaxa, 1265, 1-80.

Okamoto, R. (1963): On the problems of a monogenetic trematode infection of tiger puffer from the Inland Sea of Japan. Suisanzoshoku (Special Issue), 3, 17-29. (in Japanese)

Rambaut, A. (2001): Sequence alignment editor (Se-Al), version 2.0a9. Oxford University, Oxford, UK.

Smith, J. W. (2001): The family Sanguinicolidae von Graff, 1907. In: Keys to the trematoda, Vol. 1. (ed. by D. I. Gibson, A. Jones and R. A. Bray), CABI Publ., Wallingford, pp. $434-452$.

Swofford, D. L. (1998): PAUP*. Phylogenetic analysis using parsimony ("and other methods), version 4.0b8. Sinauer Associates, Sunderland, MA, USA.

Takaoka, O. (2000): Tiger puffer. In "Culture of marine fish (latest version)" (ed. by H. Kumai). Sobunsha, Tokyo, pp. 140-147. (in Japanese)

Yamaguti, S. (1938): Studies on the helminth fauna of Japan. Part 21. Trematodes of fishes, IV. Publ. by author, 1138.

Yamaguti, S. (1951): Studies on the helminth fauna of Japan. Part 48. Trematodes of fishes, X. Arb. Med. Fak. Okayama, 7, 315-334.

Yamaguti, S. (1958): Systema Helminthum. Vol. I. The digenetic trematodes of vertebrates. Interscience Publ., New York, $1575 \mathrm{p}$. 